\title{
Characterization of Bacteriophage SPP1 Transducing Particles
}

\author{
By HERMINIA DE LENCASTRE* AND LUIS J. ARCHER \\ Departamento de Biologia e Bioengenharia, Universidade Nova de Lisboa, and Grupo \\ de Genética Molecular, Instituto Gulbenkian de Ciência, Oeiras, Portugal
}

(Received 3 July 1979; revised 26 September 1979)

\begin{abstract}
Bacillus subtilis lysates produced by virulent bacteriophage SPP1 retained their transducing ability upon purification from contaminating PBSX particles. The buoyant density in $\mathrm{CsCl}$ of the transducing activity was indistinguishable from that of the SPP1 plaque-forming units and the sedimentation behaviour in sucrose gradients of purified transducing particles was the same as that of SPP1 phage particles. Further, high concentrations of anti-SPP1 serum inactivated transducing particles and SPP1 plaque-forming units at the same rate. The transduction process was resistant to DNAase treatment, but was enhanced by temperatures that did not allow transformation. It was concluded that particles of the size, shape, density and serum-sensitivity characteristic of SPP1, but carrying bacterial DNA, are vectors in a true transduction process. Cell survival upon SPP1 infection is discussed.
\end{abstract}

\section{INTRODUCTION}

Generalized transduction is a powerful method for fine structure genetic analysis. For generalized transduction in Bacillus subtilis, the main bacteriophages used have been PBS1 and SP10 (Takahashi, 1961; Thorne, 1961; Young \& Wilson, 1974). Only recently has it been shown that lysates from the virulent bacteriophage SPP1 also mediate generalized transduction (Yasbin \& Young, 1974). This latter system seems to overcome some of the limitations of the other two. Bacteriophage PBS1 is flagella-specific and lyses only highly motile cells (Frankel \& Joys, 1966). In addition, it is appropriate for gross mapping, but not for fine structure analysis. Phage SP10 can be used for fine structure analysis, but only mediates heterologous transduction in $B$. subtilis 168 ; it grows well in $B$. subtilis W23 but not in $B$. subtilis 168 strains. In contrast, bacteriophage SPP1 grows readily in B. subtilis 168 derivatives and the resulting lysates mediate homologous transduction. Further, linkage data show that this system is useful for fine structure analysis (Yasbin \& Young, 1974). However, infection of $B$. subtilis by SPP1 induces the lysogenic and defective bacteriophage PBSX (Ganesan et al., 1976). Since this latter phage is known to mediate gene transfer in B. subtilis (Haas \& Yoshikawa, 1969b), the involvement of SPP1 particles in the transducing activity of SPP1 lysates could be questioned.

We decided, therefore, to characterize the particles associated with the transducing activity of SPP1 lysates from which PBSX particles had been removed. Some preliminary results have been published (Lencastre \& Archer, 1979). Here we describe further observations showing that SPP1 particles are vectors in a true transduction process. 
Table 1. Bacterial and bacteriophage strains

Strain
Bacillus subtilis 17
B. subtilis TV173
B. subtilis VUB112
B. subtilis VUB112 $\mathrm{t}^{+}$
B. subtilis BR151

Bacteriophage SPP1 wt Bacteriophage SPP1 $t s 3$

\author{
Genotype \\ thy $A$ thy B leu-2 \\ hisB metB10 su-3* \\ thy $A$ thy $B \operatorname{trp} C 25 \mathrm{BU}^{\mathrm{t}}+$ \\ thy $A$ thy $B \mathrm{BU}^{\mathrm{t}} \dagger$ \\ lys-3 trpC2 metB10 \\ Wild type \\ Defective in DNA synthesis \\ at $46^{\circ} \mathrm{C}$ \\ Source/reference \\ Transformation of SB566 (Farmer \& \\ Rothman, 1965) \\ Obtained from F. Young (Yasbin \& \\ Young, 1974) \\ Obtained from N. Harford \\ Transformation of VUB112 with DNA \\ from a $168 \mathrm{~T}^{+}$obtained from $\mathrm{F}$. Young \\ Obtained from F. Young (Yasbin \& \\ Young, 1974) \\ Obtained from F. Young \\ Obtained from T. A. Trautner (Spatz \\ \& Trautner, 1971) \\ * Suppressor mutation isolated by Georgopoulos (1969). \\ $\uparrow$ 5-Bromouracil-tolerant mutation (Bishop \& Sueoka, 1972).
}

\section{METHODS}

Strains. Bacterial and bacteriophage strains are listed in Table 1.

Media. M broth, M semi-solid agar and minimal medium were described by Yasbin \& Young (1974). Tryptone/yeast extract (TY) medium, SSC (standard saline sodium citrate), Tris/ $\mathrm{HCl}$ and TBT buffer were prepared as reported by Biswal et al. (1967). Penassay broth was antibiotic medium no. 3 (Difco). III/H medium was a modification developed in Dr T. A. Trautner's laboratory of MIIIS and MIIIM medium (Esche et al., 1975). It contained (per litre deionized water): $1.4 \mathrm{~g} \mathrm{~K}_{2} \mathrm{HPO}_{4}, 0.56 \mathrm{~g} \mathrm{KH}_{2} \mathrm{PO}_{4}, 1.32 \mathrm{~g}\left(\mathrm{NH}_{4}\right)_{2} \mathrm{SO}_{4}$, $2.94 \mathrm{~g}$ sodium citrate $2 \mathrm{H}_{2} \mathrm{O}, 3.9 \mathrm{~g} \mathrm{MgSO}_{4} .7 \mathrm{H}_{2} \mathrm{O}, 0.028 \mathrm{~g} \mathrm{MnSO}_{4} .4 \mathrm{H}_{2} \mathrm{O}, 1.5 \mathrm{~g}$ asparagine, $0.243 \mathrm{mg}$ $\mathrm{FeCl}_{3} .6 \mathrm{H}_{2} \mathrm{O}, 7 \mathrm{~g}$ D-glucose, $25 \mathrm{ml}$ amino acid solution and $3.5 \mathrm{ml}$ vitamin solution. The amino acid solution contained the following amino acids, each at $80 \mu \mathrm{g} \mathrm{ml}^{-1}$ : Ala, Arg, Asp, Cys, Glu, Gly, His, lle, Leu, Lys, Met, Phe, Pro, Ser, Thr, Tyr, Val and Trp. The vitamin solution was prepared as described by Kahmann (1974). When necessary the medium was supplemented with the requirements of the strain $\left(60 \mu \mathrm{g} \mathrm{ml}^{-1}\right)$.

Chemicals. Anti-SPP1 rabbit serum $\left(K=100 \mathrm{~min}^{-1}\right)$ was a gift from $\mathrm{Dr}$ T. A. Trautner. [methyl- ${ }^{3} \mathrm{H}$ Thymidine $\left(23 \mathrm{Ci} \mathrm{mmol}^{-1} ; 850 \mathrm{GBq} \mathrm{mmol}^{-1}\right)$ and $\left[2{ }^{-14} \mathrm{C}\right]$ thymine $\left(59 \mathrm{mCi} \mathrm{mmol}{ }^{-1} ; 2 \cdot 2 \mathrm{GBq} \mathrm{mmol}^{-1}\right)$ were obtained from The Radiochemical Centre, Amersham. Pancreatic deoxyribonuclease Type I (DNAase), ribonuclease $T_{1}$, ribonuclease A and pronase were obtained from Sigma.

Calculation of adsorption efficiencies. Strain BR151 was grown overnight in supplemented III/H medium at $37^{\circ} \mathrm{C}$ with vigorous aeration. The overnight culture was centrifuged, resuspended in the same medium (twice the original volume) and incubated at $37^{\circ} \mathrm{C}$ with vigorous aeration for $1 \mathrm{~h}$. The culture was then concentrated by centrifugation to a density of $2 \times 10^{9}$ cells $\mathrm{ml}^{-1}$ and phages were added at the desired input multiplicity. After $9 \mathrm{~min}$ incubation the culture was centrifuged at $8000 \mathrm{~g}$ for $5 \mathrm{~min}$ at $4{ }^{\circ} \mathrm{C}$, together with control samples in which bacterial suspension was replaced by III/H medium. The number of unadsorbed bacteriophages was calculated by titration of the supernatants.

Preparation of lysates. (i) Using unlabelled bacteria. SPP1 lysates were prepared on B. subtilis 17 or TV173 essentially as described by Biswal et al. (1967). Phages were added at an input multiplicity of 5. After infection, incubation was continued at $37^{\circ} \mathrm{C}$ (or at $30^{\circ} \mathrm{C}$ when using SPP1 $t s 3$ ) for $6 \mathrm{~h}$. After overnight storage at $4{ }^{\circ} \mathrm{C}$, phages were purified and concentrated.

(ii) Using ${ }^{3} \mathrm{H}$-labelled bacteria. For ${ }^{3} \mathrm{H}$ labelling of transducing particles, the above procedure was modified: the overnight $B$. subtilis 17 culture contained thymine $\left(5 \mu \mathrm{g} \mathrm{ml}^{-1}\right)$, and the subsequent dilution and incubation were done in the same medium to which $\left[\right.$ methyl $\left.{ }^{3} \mathrm{H}\right]$ thymidine $\left(10 \mu \mathrm{Ci} \mathrm{m} l^{-1}\right)$ was added. The culture was infected and treated as described by Ebel-Tsipis et al. (1972).

Preparation of ${ }^{14} \mathrm{C}$-labelled phages. ${ }^{14} \mathrm{C}$-labelled SPP1 phages were prepared by the method described by Kahmann (1974). The procedure was similar to that used for the preparation of lysates using unlabelled bacteria (above), but with the following modifications. The overnight $B$. subtilis VUB $112 \mathrm{t}^{+}$culture contained thymine $\left(5 \mu \mathrm{g} \mathrm{ml}^{-1}\right)$. Before phage infection the culture was centrifuged, washed once in $\mathrm{III} / \mathrm{H}$ medium containing thymine $\left(5 \mu \mathrm{g} \mathrm{ml}^{-1}\right)$ and incubated for $15 \mathrm{~min}$ in the same volume of the same medium to which $\left[{ }^{14} \mathrm{C}\right]$ thymine $\left(5 \mu \mathrm{Ci} \mathrm{ml}{ }^{-1}\right)$ was added. These ${ }^{14} \mathrm{C}$-labelled phages were analysed simultaneously with ${ }^{3} \mathrm{H}$-labelled lysates in a $\mathrm{CsCl}$ equilibrium density gradient and in a sucrose gradient (see Results).

Titration of the lysates. Indicator bacteria (BR151) were grown in Penassay broth or TY medium to a 
density of $1 \times 10^{8}$ to $2 \times 10^{8}$ cells $\mathrm{ml}^{-1}$. Plates were prepared by embedding $0 \cdot 1 \mathrm{ml}$ indicator bacteria in $\mathrm{M}$ agar together with an appropriate inoculum of a dilution of the lysate in TBT buffer. Plates were incubated at $37^{\circ} \mathrm{C}$ (or $30^{\circ} \mathrm{C}$ for $t s 3$ phage).

Concentration and purification of lysates. Phages were separated from bacterial debris and concentrated by high-speed centrifugation as described by Ebel-Tsipis et al. (1972). With lysates exceeding 500 ml, phages were concentrated by means of polyethylene glycol 6000 (PEG) as described by Yamamoto et al. (1970) using $12 \%(\mathrm{w} / \mathrm{v})$ PEG. Phages concentrated by either of the above methods were further purified in a discontinuous $\mathrm{CsCl}$ gradient (densities $1 \cdot 7,1 \cdot 5,1 \cdot 3 \mathrm{~g} \mathrm{ml}^{-1}$ ) containing $0.01 \mathrm{M}-\mathrm{MgCl}_{2}$. The SPP1 phages appeared as a blue opalescent band; this band is the one of higher density in the gradient and having plaque-forming activity in $B$. subtilis 168 . The SPP1-containing band was collected with a Pasteur pipette after carefully removing all the material above it. $\mathrm{CsCl}$ was removed by successive dialyses at $4{ }^{\circ} \mathrm{C}$ against $\mathrm{NaCl}$ at $2,1,0 \cdot 5$ and $0.25 \mathrm{M}$, followed by three extensive dialyses against TBT buffer. Stocks with titres of $2 \times 10^{12}$ to $8 \times 10^{12}$ phages $\mathrm{ml}^{-1}$ were stored at $4{ }^{\circ} \mathrm{C}$ with a few drops of chloroform.

Transduction procedure. Unless otherwise indicated, the recipient (B. subtilis BR151) was grown overnight in supplemented III/H medium at $37^{\circ} \mathrm{C}$ with vigorous aeration. The overnight culture was centrifuged, resuspended in the same medium (twice the original volume) and incubated at $37^{\circ} \mathrm{C}$ with vigorous aeration for $1 \mathrm{~h}$. Phages were added, and adsorption was allowed to occur for 20 to $30 \mathrm{~min}$ at the same temperature (unless otherwise indicated) with shaking and in the presence of DNAase $\left(100 \mu \mathrm{g} \mathrm{ml}^{-1}\right)$. Infected bacteria were washed twice in unsupplemented $\mathrm{III} / \mathrm{H}$ medium and resuspended in minimal medium (half the original volume). The bacteria were embedded in minimal agar supplemented with two of the three required amino acids $\left(50 \mu \mathrm{g} \mathrm{ml}^{-1}\right.$ each) and acid-hydrolysed casein $\left(50 \mu \mathrm{g} \mathrm{ml}^{-1}\right)$. The plates were incubated for 24 to $48 \mathrm{~h}$ at $46^{\circ} \mathrm{C}$ (see Results). When only trp ${ }^{+}$transductants were selected, ten times more casein was added to the plates. In the experiments to study the effect of temperature on transduction the above procedure was modified. Recipient cultures were infected with $t s 3$ and $w t$ SPP1 at different input multiplicities; transduction reactions were stopped after 20 min incubation by adding anti-SPP1 serum, dilutions were made (thus eliminating further action of the serum), and samples were plated to determine the numbers of transductants, plaque-forming units and colony-forming units.

DNA isolation. Phage DNA was isolated by phenol extraction (Biswal et al., 1967) and dialysed against SSC, unless otherwise indicated. Bacterial DNA was extracted with phenol by the method of Young \& Wilson (1974), except that ribonuclease $\mathrm{A}\left(60 \mu \mathrm{g} \mathrm{ml}^{-1}\right)$ and ribonuclease $\mathrm{T}_{1}\left(40 \mu \mathrm{g} \mathrm{ml}^{-1}\right)$ were added, and pronase treatment $\left(1 \mu \mathrm{g} \mathrm{ml}^{-1}\right)$ was performed overnight at $37^{\circ} \mathrm{C}$. Ribonuclease $\mathrm{A}$ and pronase solutions were heated at $80^{\circ} \mathrm{C}$ for $10 \mathrm{~min}$ before use. DNA concentration was measured spectrophotometrically at $260 \mathrm{~nm}$.

CsCl gradient centrifugation. $\mathrm{CsCl}$ gradients for DNA were prepared by adding $2.49 \mathrm{~g}$ solid $\mathrm{CsCl}$ to $1.95 \mathrm{ml}$ of $0.01 \mathrm{M}$-Tris/0.01 M-EDTA, pH 8.0; the density of the final solution was adjusted to $1.708 \mathrm{~g} \mathrm{ml}^{-1} . \mathrm{CsCl}$ gradients for phage particles were prepared by adding $\mathrm{CsCl}$ to purified phage particles to a final density of $1.544 \mathrm{~g} \mathrm{ml}^{-1}$. Fractions were collected from the bottom of the gradient, without piercing the tube, through a needle connected to a capillary tube on which a peristaltic pump acted.

Zone sedimentation through sucrose gradients. Sucrose gradients were prepared over a $0 \cdot 1 \mathrm{ml}$ cushion of $60 \%(\mathrm{w} / \mathrm{v})$ sucrose by the method of Britten \& Roberts (1960), using $1.9 \mathrm{ml}$ of $5 \%$ sucrose and $1.7 \mathrm{ml}$ of $20 \%$ sucrose, both prepared in $0.01 \mathrm{~m}-\mathrm{EDTA} / 0 \cdot 5 \mathrm{M}-\mathrm{NaCl}, \mathrm{pH} 8 \cdot 0$.

Measurement of radioactivity. Radioactive samples were collected on $25 \mathrm{~mm}$ glass-fibre discs (Whatman glass-microfibre papers GF/C $2.5 \mathrm{~cm}$ ) and subsequently precipitated and dehydrated by standard procedures. Radioactivity was determined in scintillation fluid [4 g 2,5-diphenyloxazole and $0 \cdot 25 \mathrm{~g}$ 1,4-bis-2(4-methyl-5-phenyloxazolyl)benzene per litre toluene] in a Packard liquid scintillation counter, model 3320. When samples labelled with both ${ }^{14} \mathrm{C}$ and ${ }^{3} \mathrm{H}$ were counted, the procedure of Kobayashi \& Maudsley (1970) was followed.

\section{RESULTS \\ Efficiency of adsorption}

In view of difficulties in adsorption of SPP1 to bacteria (Yasbin \& Young, 1974) several different conditions and media were examined; III/H medium was finally selected. Repeated tests showed that, using this medium, 99 to $100 \%$ of the plaque-forming units adsorbed to the bacteria when the input multiplicity was $0 \cdot 1$ or lower. Even at input multiplicities of 10 , at least $50 \%$ of the phages adsorbed to the bacteria. These values applied to $w t$ SPP1 as well as to the $t s 3$ mutant. Using III/H medium and input multiplicities of 5 or 10 , the 

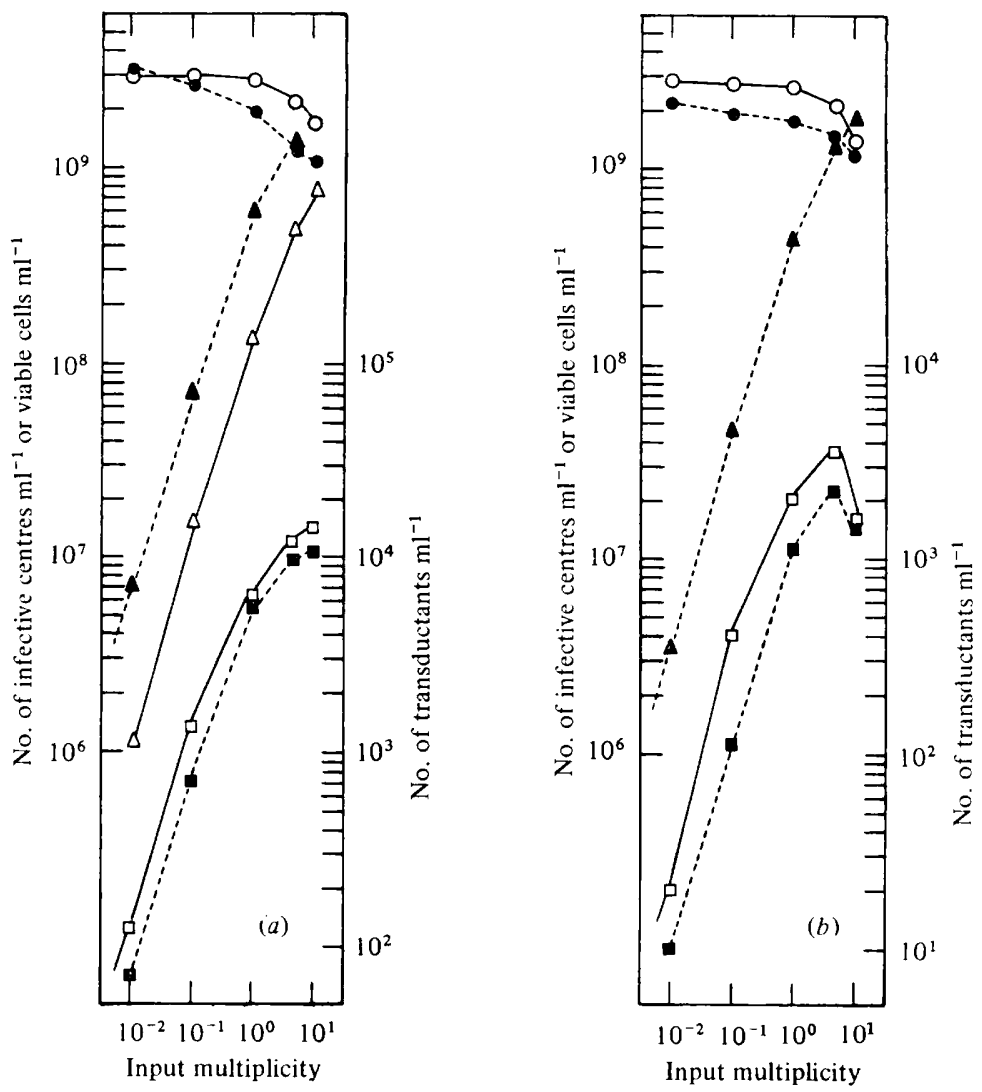

Fig. 1. Effect of temperature on transduction, phage multiplication and cell survival in bacterial cultures infected at different input multiplicities with $w t$ and $t s 3$ SPP1 lysates. Cultures of strain BR151 were prepared for transduction as described in Methods, except that, before infection, the cultures were washed twice with supplemented III/H medium deprived of tryptophan and resuspended in the same medium (one-tenth of the previous volume) to a density of about $3 \times 10^{9}$ cells $\mathrm{ml}^{-1}$. After equilibration at 30 or $46^{\circ} \mathrm{C}$, samples were incubated at the indicated input multiplicities with $w t(a)$ and $t s 3(b)$ SPP1 lysates. After 20 min incubation, anti-SPP1 serum was added (final concentration $10^{-2}$ ); incubation was then continued for another $5 \mathrm{~min}$. The numbers of $\operatorname{trp}^{+}$transductants $\mathrm{ml}^{-1}\left(\square\right.$ for $30^{\circ} \mathrm{C}$ and $\square$ for $46^{\circ} \mathrm{C}$ ), infective centres $\mathrm{ml}^{-1}\left(\Delta\right.$ for $30^{\circ} \mathrm{C}$ and $\triangle$ for $46^{\circ} \mathrm{C}$ ) and colony-forming units $\mathrm{ml}^{-1}\left(\bigcirc\right.$ for $30^{\circ} \mathrm{C}$ and $\bigcirc$ for $46^{\circ} \mathrm{C}$ ) were then determined. The number of infective centres obtained with the $t s 3$ mutant at $46{ }^{\circ} \mathrm{C}$ was $<10^{3} \mathrm{ml}^{-1}$ (not shown).

frequencies of transduction (transductants per viable cell) were frequently higher than $1 \times 10^{-5}$.

\section{Effect of temperature}

To assess the possible loss of transductants through lytic activity of the infecting bacteriophages, the temperature-sensitive SPP1 ts3 mutant (Spatz \& Trautner, 1971) was utilized as vector. This mutant is defective in DNA synthesis (T. A. Trautner, personal communication). Its efliciency of plating at $46{ }^{\circ} \mathrm{C}$ was $10^{-6}$ compared with that at $30^{\circ} \mathrm{C}$, but its adsorption was normal and independent of temperature variations between 30 and $46^{\circ} \mathrm{C}$. When transduction was carried out at $46{ }^{\circ} \mathrm{C}$ using $t s 3$ lysates, the number of transductants $\mathrm{ml}^{-1}$ was, as expected, always higher than that obtained at $30^{\circ} \mathrm{C}$.

A comparison of $t s 3$ and $w t$ SPP1 at different input multiplicities (Fig. 1) showed that, in general, up to an input multiplicity of 1 , the number of infective centres and transductants increased at the same rate, with a slope of 1 . At higher input multiplicities the two curves 


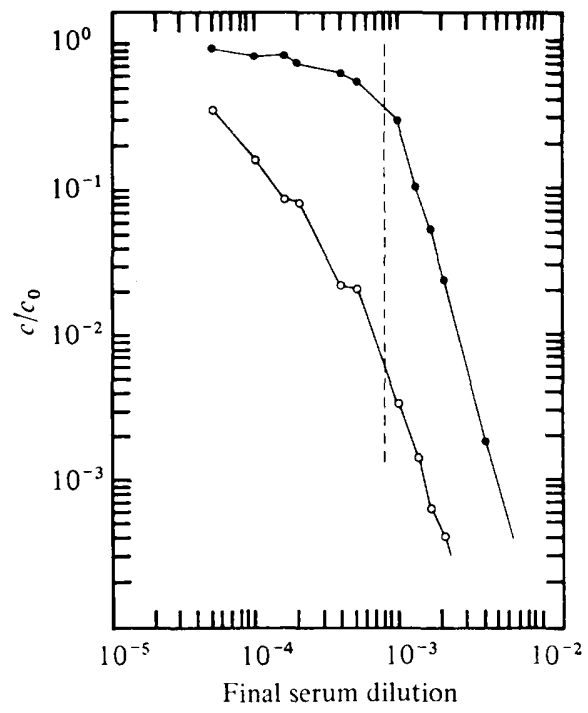

Fig. 2. Inactivation by anti-SPP1 serum of gene transfer and infectious activity of a transducing lysate. Samples of a wt SPP1 lysate diluted in III/H medium were incubated for $15 \mathrm{~min}$ at $37^{\circ} \mathrm{C}$ with different dilutions of anti-SPP1 serum. To a control sample no serum was added. Plaqueforming units $(O)$ and $t r p^{+}$transductants $(O)$ were determined as described in Methods. The input multiplicity used was 140 . The plates were incubated at $46{ }^{\circ} \mathrm{C}$. $c$ is the number of plaque-forming units or transductants obtained in the presence of anti-SPPl serum, and $c_{0}$ is the number of plaqueforming units or transductants obtained in the absence of anti-SPP1 serum. The dashed line indicates the serum concentration which reduced the actual multiplicity of infection to 1 .

deviated differently from that slope. Probably, the concentration of infective particles was then approaching saturation and potential transductants might be affected by the higher number of cells killed by infection.

As expected, there was a drastic reduction of $t s 3$ plaque-forming units at $46{ }^{\circ} \mathrm{C}$ (about $10^{6}$ less than at $30^{\circ} \mathrm{C}$ ), while $w t$ plaque-forming units only decreased five- to sixfold. Surprisingly, however, the twofold increase in the absolute number of transductants and surviving cells at the higher temperature appeared to be similar for both the $w t$ and $t s 3$.

When bacterial samples from our transduction experiments were incubated with transforming DNA instead of transducing lysate, in the absence of DNAase, $2 \times 10^{3}$ to $5 \times 10^{3}$ trp $p^{+}$transformants $\mathrm{ml}^{-1}$ were obtained at 30 or $37^{\circ} \mathrm{C}$, but, in contrast, no transformants $\left(<1 \mathrm{ml}^{-1}\right.$ ) were recovered at $46^{\circ} \mathrm{C}$ (results not shown).

In view of the results obtained most of the subsequent experiments were performed with either phage strain at $46{ }^{\circ} \mathrm{C}$, a temperature which also allowed faster growth of the transductants.

\section{Inactivation of transducing and plaque-forming particles by anti-SPP1 serum}

Samples of a wt SPP1 lysate were incubated for $15 \mathrm{~min}$ at $37^{\circ} \mathrm{C}$ with different amounts of anti-SPP1 serum and then diluted and tested for transducing and plaque-forming ability (Fig. 2). At dilutions of the serum lower than $8 \times 10^{-4}$, transducing activity and plaqueforming ability were equally inactivated. This showed that both activities were related to the same particle type. At higher dilutions of the serum, the two curves were not parallel. This result was not surprising. An analogous pattern was observed in the dose-response experiment (Fig. 1) at input multiplicities higher than 1. It can also be shown that an effective input multiplicity of 1 was obtained at the serum dilution of $8 \times 10^{-4}$. At this dilution, the value of $c / c_{0}$ found for plaque-forming units was $7 \times 10^{-3}$ (Fig. 2). Since the 


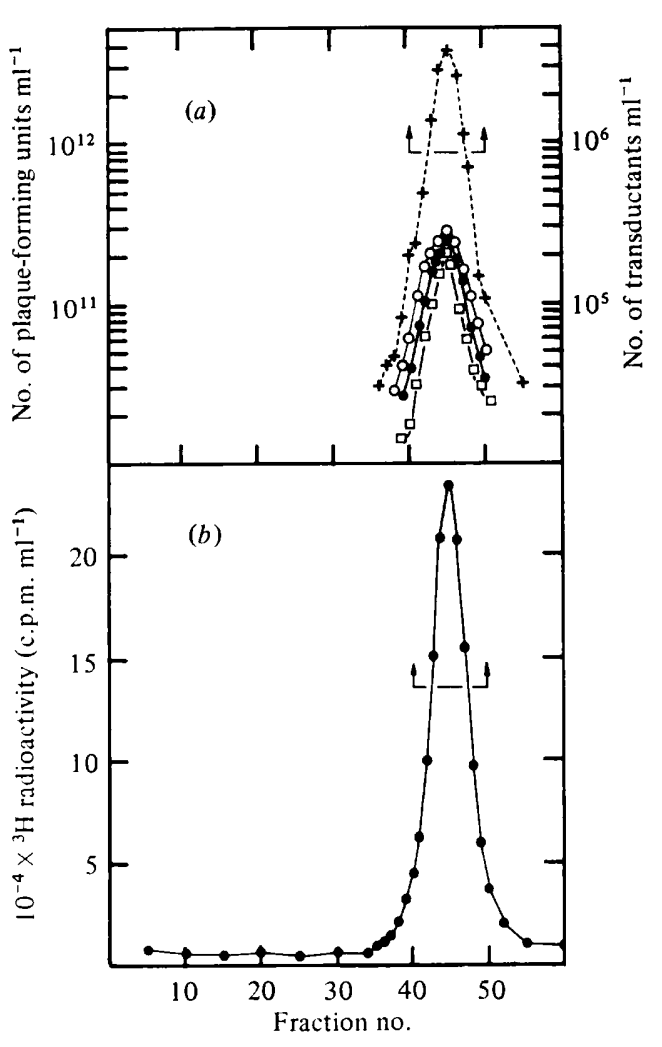

Fig. 3

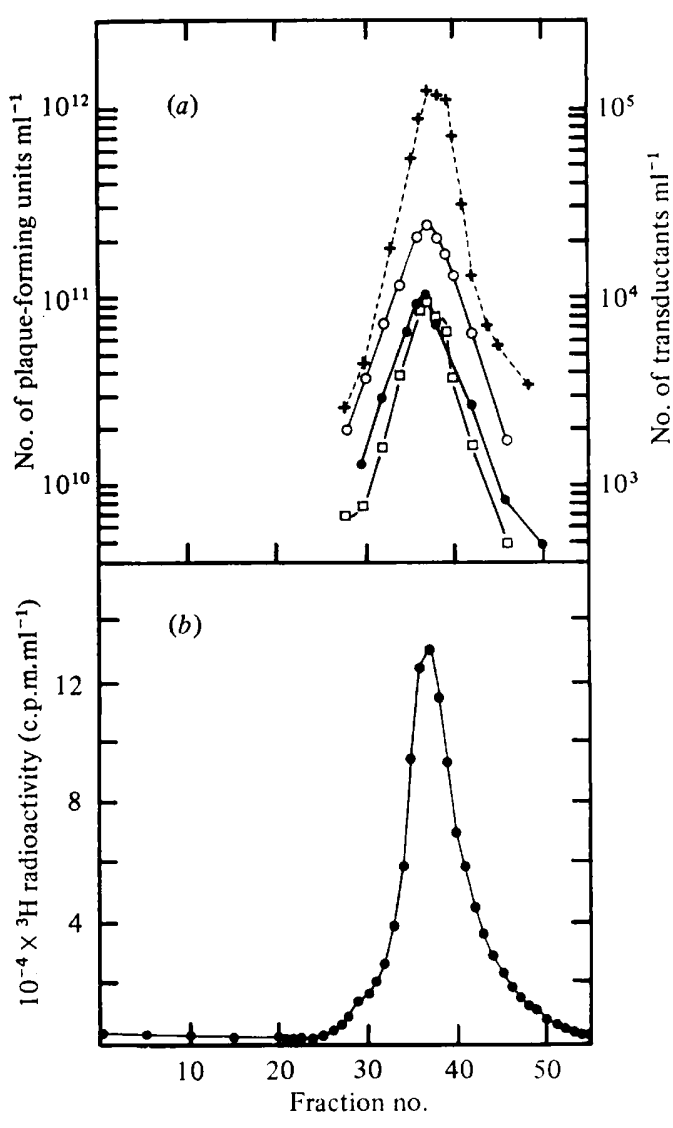

Fig. 4

Fig. 3. $\mathrm{CsCl}$ equilibrium density gradient analysis of a phage lysate. Six $\mathrm{ml}$ of a $t s 3 \mathrm{SPPI}$ lysate prepared in $\left[{ }^{3} \mathrm{H}\right]$ thymidine-labelled bacteria was mixed with $\mathrm{CsCl}$ to a final volume of $28.6 \mathrm{ml}$. The mixture was centrifuged at $70000 \mathrm{~g}$ for $24 \mathrm{~h}$ at $16^{\circ} \mathrm{C}$ in a IEC SB-110 rotor. A total of 75 fractions of 15 drops each were collected. (a) Fractions were assayed for plaque-forming units $(+)$ and for $\mathrm{met}^{+}(\bigcirc), \mathrm{lss}^{+}(\bigcirc)$ and $\mathrm{trp}^{+}(\square)$ transducing activity. (b) Samples $(50 \mu \mathrm{l})$ from the fractions indicated were assayed for radioactivity.

Fig. 4. Refractionation of the peak from the gradient represented in Fig. 3. Fractions 43 to 47 (indicated by arrows in Fig. 3) were pooled and centrifuged in $\mathrm{CsCl}$ at $100000 \mathrm{~g}$ for $24 \mathrm{~h}$ at $16^{\circ} \mathrm{C}$ in a IEC SB-283 rotor. A total of 84 fractions of 5 drops each were collected. $(a)$ Fractions indicated were assayed for plaque-forming units $(+)$ and for $m e t^{+}(O), l y s^{+}(O)$ and $\operatorname{trp}^{+}(\square)$ transducing activity. (b) Samples $(20 \mu \mathrm{l})$ from the fractions indicated were assayed for radioactivity.

initial input multiplicity was 140 , and $7 \times 10^{-3} \times 140$ is close to unity, this serum concentration is expected to have inactivated all but one phage per bacterium.

\section{Density of transducing and phage particles}

A $t s 3$ SPP1 lysate prepared in ${ }^{3} \mathrm{H}$-labelled bacteria was analysed in a $\mathrm{CsCl}$ equilibrium density gradient (Fig. 3). No difference could be detected between the densities of plaqueforming units and transducing activity for three markers tested.

Five fractions around the peak from this gradient were pooled and refractionated (Fig. 4). Again, no difference in density could be detected. Identical results (not shown) were obtained by co-centrifugation of ${ }^{14} \mathrm{C}$-labelled $w t$ SPP1 phages and ${ }^{3} \mathrm{H}$-labelled $t s 3$ lysates showing that the two phage strains had the same density.

Since SPP1 and B. subtilis DNAs showed the same density in $\mathrm{CsCl}$ (Fig. 5), it was concluded that transducing particles and plaque-forming units had the same DNA to protein ratio. 


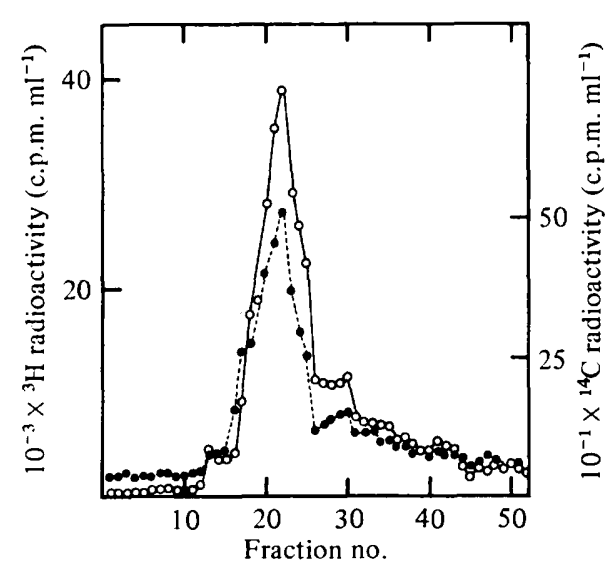

Fig. 5

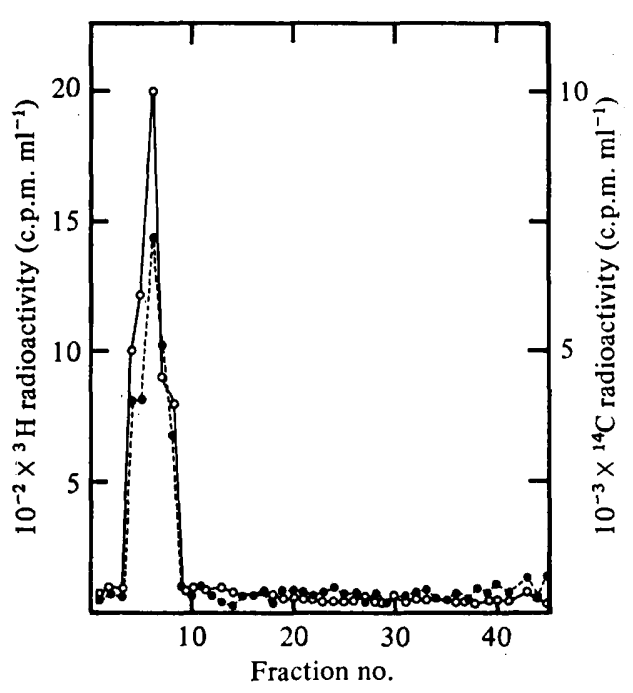

Fig. 6

Fig. 5. $\mathrm{CsCl}$ equilibrium density gradient analysis of ${ }^{3} \mathrm{H}$-labelled $B$. subtilis $\mathrm{DNA}$ and ${ }^{14} \mathrm{C}$-labelled SPP1 DNA. The gradient was centrifuged at $130000 \mathrm{~g}$ for $67 \mathrm{~h}$ at $16^{\circ} \mathrm{C}$ in a IEC SB- 405 rotor. Twodrop fractions were collected from the bottom of the tube on glass-fibre discs and assayed for ${ }^{3} \mathrm{H}$ $(\bigcirc)$ and ${ }^{14} \mathrm{C}(\mathrm{O})$ radioactivity.

Fig. 6. Zone sedimentation analysis of transducing particles. ${ }^{3} \mathrm{H}$-labelled transducing particles purified from phage particles (Lencastre \& Archer, 1979) were centrifuged in a neutral sucrose gradient together with ${ }^{14} \mathrm{C}$-labelled SPP1 as a position marker. The gradient was centrifuged at $25000 \mathrm{rev}$. $\min ^{-1}$ for $45 \mathrm{~min}$ at $10^{\circ} \mathrm{C}$ in a Spinco SW50 rotor. Two-drop fractions were collected from the bottom on glass-fibre discs and assayed for ${ }^{3} \mathrm{H}(\mathrm{O})$ and ${ }^{14} \mathrm{C}(\mathrm{O})$ radioactivity.

\section{Size and shape of transducing particles}

The density experiments did not exclude the possibility that transducing particles and plaque-forming particles might differ in absolute size. Therefore, the density label 5-bromo$2^{\prime}$-deoxyuridine was introduced into the transducing particles so that they could be separated from the phage particles in a $\mathrm{CsCl}$ equilibrium density gradient (Lencastre \& Archer, 1979). The density label, however, does not change the sedimentation coefficient of the transducing particles in sucrose gradients (Ebel-Tsipis et al., 1972). When the ${ }^{3} \mathrm{H}-$ and density-labelled transducing particles were analysed in a 5 to $20 \%$ sucrose gradient together with ${ }^{14} \mathrm{C}$-labelled SPP1 bacteriophages, the two types of particles had indistinguishable sedimentation behaviour (Fig. 6) indicating that they had the same size and shape.

\section{DISCUSSION}

SPP1 is vector in gene transfer. Since the buoyant density of PBSX in CsCl $\left(1.375 \mathrm{~g} \mathrm{ml}^{-1}\right.$; Haas \& Yoshikawa, 1969a) is different from that of SPP1 (around $1.54 \mathrm{~g} \mathrm{ml}^{-1}$; from our data), PBSX particles were probably excluded from our preparations by the initial purification of the lysates on discontinuous $\mathrm{CsCl}$ gradients. Yet, the purified lysates retained high transducing ability. Furthermore, the buoyant density in $\mathrm{CsCl}$ of the transducing activity was indistinguishable from that of the SPP1 plaque-forming units (Figs 3 and 4) as was the buoyant density of $B$. subtilis DNA from SPP1 DNA (Fig. 5). In addition, the sedimentation behaviour of purified transducing particles was the same as that of SPP1 phage particles (Fig. 6). These results strongly suggest that SPP1 is a vector in the transduction process. This was supported by the inactivation of transducing and infective particles by anti-SPPI serum. The pattern of these inactivations (Fig. 2) paralleled those obtained as a function of decreasing input multiplicities (Fig. 1). Most probably the anti-SPP1 serum used also con- 
tained anti-PBSX activity. Nevertheless, our results argue in favour of the transducing and plaque-forming activities being related to the same particle type. It is most unlikely that two different antigens, when injected in unknown proportion, would stimulate the production of a serum of identical titre for each. We conclude, therefore, that transducing activiiy is carried in particles of the size, shape, density and serum sensitivity characteristic of bacteriophage SPP1.

SPP1 mediates true transduction. The SPP1-mediated gene transfer seems to follow a true transduction mechanism which excludes the transformation-like penetration of DNA reported for some other transduction systems (Haas \& Yoshikawa, 1969 b; Porter et al., 1979). This conclusion is based on the DNAase-resistance of the transduction process and on its insensitivity to a temperature $\left(46^{\circ} \mathrm{C}\right)$ at which there was no DNA-mediated transformation.

It has been shown that certain temperatures, although not high enough to affect the viability of non-competent $B$. subtilis bacteria, cause rapid death of competent and newly transformed bacteria in the same culture (Archer, 1973). It is likely that this is the cause of the loss of transformants at $46^{\circ} \mathrm{C}$ described here. Assuming this, it is clear that recipient bacteria for transduction are not selected preferentially from among the competent bacteria of the culture.

Cell survival upon SPP1 infection. Yasbin \& Young (1974) observed that SPP1 infection, even at input multiplicities of 200 , allowed the survival of a substantial fraction of the population. This may not be attributable to the low adsorption obtained under their conditions. Even under our conditions of good adsorption similar high values for survival were obtained (Fig. 1 and unpublished observations). The possibility of mutation to phage resistance, lysogeny or pseudo-lysogeny does not explain the high survival values of infected cultures. Several clones isolated from cells surviving SPPI infection (both transductants and non-transductants) were tested and all showed normal sensitivity to the phage (unpublished observations). The killing capacity of SPP1 does not depend on virus DNA replication as the killing capacity of the $t s 3$ mutant at $46^{\circ} \mathrm{C}$ was similar to that of the $r \cdot t$ (Fig. 1).

The reason for the high cell survival of infected cultures is not known. It is worth noting, however, that phage production in bacteria infected in liquid medium appears to te lower than that of bacteria infected in solid medium. The input multiplicity of $10^{-2}$, for instance, corresponds in Fig. 1 to $3 \times 10^{7}$ plaque-forming units (titrated on solid medium) $\mathrm{ml}^{-1}$ of liquid culture. After the $20 \mathrm{~min}$ incubation, only $3 \cdot 5 \times 10^{6} t s 3$ and $7 \times 10^{6} \mathrm{w} t$ infective centres were recovered at $30^{\circ} \mathrm{C}$. At other input multiplicities which allow high adsorption only $1 / 4$ of the $w t$ phage and about $1 / 10$ of the $t s 3$ mutants originated infective centres in liquid. Those bacteria that fail to be killed by infection must still be sensitive to transduction, as the frequency of transductants is high even at high input multiplicities.

We wish to thank Dr F. E. Young and Dr A. Wilson for introducing us to technical details of the system and for constant encouragement, Dr T. A. Trautner for helpful discussions and for the gift of anti-SPP1 serum, Drs M. S. Fox, P. J. Piggot and F. E. Young for constructive criticism of the manuscript, Mrs M.C. Lopes for excellent technical assistance and $\mathrm{Mr} \mathrm{M}$. Guimarães for drawing the figures.

\section{REFERENCES}

ArCHER, L. J. (1973). Heat sensitivity of competent and pre-competent cells of Bacillus subtilis. In Bacterial Transformation, pp. 45-63. Edited by L. J. Archer. London: Academic Press.

Bishop, R. J. \& SuEOKA, N. (1972). 5-Bromouraciltolerant mutants of Bacillus subtilis. Journal of Bacteriology 112, 870-876.
Biswal, N., Kleinschmidt, A. K., Spatz, H. C. \& Trautner, T. A. (1967). Physical properties of the DNA of bacteriophage SP50. Molecular and General Genetics 100, 39-55.

Britten, R. J. \& Roberts, R. B. (1960). Highresolution density gradient sedimentation analysis. Science 131, 32-33. 
Ebel-Tsipis, J., Botstein, D. \& Fox, M. S. (1972). Generalized transduction by bacteriophage P22 in Salmonella typhimurium I. Molecular origin of transducing DNA. Journal of Molecular Biology 71, 433-448.

Esche, H., Schweiger, M. \& Trautner, T. A. (1975). Gene expression of bacteriophage SPP1. I. Phage directed protein synthesis. Molecular and General Genetics 142, 45-55.

FARMER, J. L. \& RothMAN, F. (1965). Transformable thymine-requiring mutant of Bacillus subtilis. Journal of Bacteriology 89, 262-263.

Frankel, R. W. \& JoYs, T. M. (1966). Adsorption specificity of bacteriophage PBS1. Journal of Bacteriology 92, 388-389.

Ganesan, A. T., Andersen, J. J., Luch, J. \& EFFERon, M. (1976). DNA metabolism in Bacillus subtilis and its phage SPP1. In Microbiology1976, pp. 319-325. Edited by D. Schlessinger. Washington: American Society for Microbiology.

Georgopoulos, C. P. (1969). Suppressor system in Bacillus subtilis 168. Journal of Bacteriology 97, 1397-1402.

HaAs, M. \& Yoshikawa, H. (1969a). Defective bacteriophage PBSH in Bacillus subtilis I. Induction, purification, and physical properties of the bacteriophage and its deoxyribonucleic acid. Journal of Virology 3, 233-247.

Haas, M. \& Yoshikawa, H. (1969b). Defective bacteriophage PBSH in Bacillus subtilis II. Intracellular development of the induced prophage. Journal of Virology 3, 248-260.

KaHMANN, R. (1974). Das Verhalten von SPP1 DNA nach Transfektion von B. subtilis. Doctoral thesis, Freie Universität Berlin.
Kobayashi, Y. \& Maudsley, O. V. (1970). Practical aspects of double isotope counting. In The Current Status of Liquid Scintillation Counting, pp. 76-85. Edited by E. D. Bransome. New York: Grune \& Stratton.

Lencastre, H. \& ArcheR, L. J. (1979). Transducing activity of bacteriophage SPP1. Biochemical and Biophysical Research Communications 86, 915-919.

Porter, R. D., Shoemaker, N. B., Rampe, G. \& GuILD, W. R. (1979). Bacteriophage-associated gene transfer in pneumococcus: transduction or pseudotransduction? Journal of Bacteriology 137, 556-567.

Spatz, H. Ch. \& Trautner, T. A. (1971). The role of recombination in transfection of Bacillus subtilis. Molecular and General Genetics 113, 174-190.

TAKAHASHI, I. (1961). Genetic transduction in Bacillus subtilis. Biochemical and Biophysical Research Communications 5, 171-175.

Thorne, C. B. (1961). Transduction in Bacillus subtilis. Journal of Bacteriology 83, 106-111.

Yamamoto, K. R., Alber TS, B. M., Benzinger, R., LAWhorne, L. \& Treiber, G. (1970). Rapid bacteriophage sedimentation in the presence of polyethylene glycol and its application to largescale virus purification. Virology 40, 734-744.

YASBIN, R. E. \& YounG, F. E. (1974). Transduction in Bacillus subtilis by bacteriophage SPP1. Journal of Virology 14, 1343-1348.

Young, F. E. \& WiLson, G. A. (1974). Bacillus subtilis. In Handbook of Genetics, vol. I, pp. 69144. Edited by R. C. King. New York: Plenum Press. 